\title{
Amoxycillin levels in sputum, serum, and saliva
}

\author{
SHEILA M. STEWART, ISOBEL M. E. ANDERSON, \\ G. R. JONES, and MARGARET A. CALDER \\ with the technical assistance of Kathleen C. Pratt and Margaret G. G. Malcolm \\ Departments of Bacteriology and Respiratory Diseases, University of Edinburgh and the \\ City Hospital, Edinburgh
}

\begin{abstract}
Stewart, Sheila M., Anderson, Isobel M. E., Jones, G. R., and Calder, Margaret A. (1974). Thorax, 29, 110-114. Amoxycillin levels in sputum, serum, and saliva. The levels of amoxycillin in sputum, saliva, and serum from 22 patients were estimated. Fifteen patients had pneumonia and seven had acute exacerbations of chronic bronchitis. The drug was given orally in a dose of $500 \mathrm{mg}$ four times daily.

There was considerable variation in the levels in specimens from different patients. The mean sputum levels two to three hours and six hours after the dose were 0.52 and $0.53 \mu \mathrm{g} / \mathrm{ml}$ respectively. The mean two-hour saliva level was $0.32 \mu \mathrm{g} / \mathrm{ml}$. The mean serum levels two and six hours after the test dose were 11.0 and $3.5 \mu \mathrm{g} / \mathrm{ml}$ respectively. The higher levels of amoxycillin were usually associated with the presence of more pus in the sputum. The mean levels of amoxycillin at comparable times were significantly greater than those found in a previous study after the same dose of ampicillin.

Clinical response to treatment occurred more rapidly in those patients with sputum levels of $0 \cdot 25 \mu \mathrm{g}$ amoxycillin per $\mathrm{ml}$ or above than in those with lower levels. The time taken to clear potential pathogens from the sputum was related to the pathogen rather than to the amoxycillin level, Haemophilus influenzae persisting for longer than Streptococcus pneumoniae.
\end{abstract}

Amoxycillin is a new synthetic penicillin derived from 6-amino penicillanic acid. In chemical structure and spectrum of activity it bears a close resemblance to ampicillin, but it has been suggested that it is absorbed better after oral administration (Croydon and Sutherland, 1970). The present report concerns the sputum, serum, and saliva levels of amoxycillin in patients with respiratory infections.

\section{PATIENTS}

All 22 patients were in hospital at the time of the investigation and were included in a clinical study of the use of amoxycillin in the treatment of

Requests for reprints: Dr. S. M. Stewart, Department of Bacteriology, University Medical School, Teviot Place, Edinburgh 8 pneumonia and acute exacerbations of chronic bronchitis (Jones et al., 1973). Patients were excluded from that study if they had known hypersensitivity to the penicillins, hepatic or renal disease, if they were pregnant or if they were desperately ill on admission. Nineteen were male and three female. Their ages ranged from 20 to 79 , mean age 61.5 years. Fifteen patients had clinical and radiographic evidence of pneumonia. The remaining seven patients had acute exacerbations of chronic bronchitis as defined by the Medical Research Council (1965).

TREATMENT All patients were receiving amoxycillin $500 \mathrm{mg}$ orally four times daily. Treatment had been started at least 36 hours before the assays were carried out.

On the day of assay, all but one of the patients received amoxycillin at 6.00 a.m. The test dose was given at 12 noon, before lunch. 
ASSESSMENT OF CLINICAL RESPONSE Clinical response was considered to have occurred on the first day on which patients with pneumonia became afebrile or on the first day on which the sputum of patients with bronchitis converted from mucopurulent to mucoid.

\section{METHODS}

SPECIMENS FOR ASSAY To ensure accurate timing, the test dose was administered and the specimens were collected by one of us (I.M.E.A.). Sputum and venous blood were collected before the test dose was given. Two hours later, venous blood and saliva were collected. All sputum produced up to the second hour was discarded; sputum was collected for assay between the second and third hours.

ASSAY METHOD Sputum purulence was assessed by the naked eye (Stewart, Fisher, Young, and Lutz, 1970). The specimens were assayed by the cup diffusion technique previously described (Stewart et al., 1970), using a yeast agar and Sarcina lutea as the test organism. Before assay, the sputa were homogenized in equal quantities of sterile distilled water using glass beads. Sera were tested neat and at dilutions of $1: 10$ and $1: 100$ in sterile distilled water. Specimens of saliva were tested neat after being shaken with glass beads. Twofold dilutions of amoxycillin in sterile distilled water at final concentrations of $1.0,0.5,0.25,0.12$, and $0.06 \mu \mathrm{g} / \mathrm{ml}$ were prepared immediately before use. A set of standards was included in each batch of assays for the preparation of the standard curves from which the drug levels in the test specimens were calculated. The plates were incubated for 24 hours before the zones of inhibition were measured. All specimens and standard dilutions were set up in duplicate and the mean diameters of the zones of inhibition were used in calculating the drug levels.

SPUTUM CULTURE Sputum was collected for culture for bacterial pathogens before the start of treatment and two, five, and 10 days later. The sputum was homogenized by being shaken with sterile distilled water and glass beads. Cultures were set up on blood agar and on heated blood agar, the plates being incubated in an atmosphere of $10 \% \mathrm{CO}_{2}$ at $37^{\circ} \mathrm{C}$. Mice were inoculated with homogenized sputum by the intraperitoneal route. Cultures were also set up from the assay specimens of sputum.

Striptococcus pneumoniae was identified by optochin sensitivity and Haemophilus influenzae by $\mathrm{X}$ and $\mathrm{V}$ factor dependence.

\section{RESULTS}

LEVELS OF AMOXYCILLIN IN SPUTUM, SALIVA, AND SERUM The results of sputum, saliva, and serum levels after $500 \mathrm{mg}$ of amoxycillin are shown in Table $\mathbf{I}$. There was considerable variation in the levels in specimens from different patients. Although the mean sputum levels two to three hours and six hours after the dose was given were similar, namely 0.52 and $0.53 \mu \mathrm{g} / \mathrm{ml}$, only seven of the 21 levels in the six-hour specimens were $0.5 \mu \mathrm{g} / \mathrm{ml}$ or above as compared with 13 out of the 22 specimens taken at two to three hours. The mean serum level after two hours was $11.0 \mu \mathrm{g} / \mathrm{ml}$ compared with $3.5 \mu \mathrm{g} / \mathrm{ml}$ after six hours. The mean saliva level two hours after the dose was $0.32 \mu \mathrm{g} / \mathrm{ml}$.

T A B L E I

AMOXYCILLIN LEVELS IN SPUTUM, SALIVA, AND SERUM

\begin{tabular}{|c|c|c|c|c|c|c|c|c|}
\hline \multirow{2}{*}{$\begin{array}{c}\text { Speci- } \\
\text { men }\end{array}$} & \multirow{2}{*}{$\begin{array}{l}\text { Hours } \\
\text { after } \\
\text { Dose }\end{array}$} & \multirow[t]{2}{*}{$\begin{array}{l}\text { No. of } \\
\text { Patients }\end{array}$} & \multicolumn{5}{|c|}{ Amoxycillin Level $(\mu \mathrm{g} / \mathrm{ml})$} & \multirow{2}{*}{$\begin{array}{c}\text { Mean } \\
\text { Level } \\
(\mu \mathrm{g} / \mathrm{ml})\end{array}$} \\
\hline & & & $<0.12$ & $\begin{array}{l}0 \cdot 12- \\
0 \cdot 24\end{array}$ & $\begin{array}{l}0 \cdot 25- \\
0 \cdot 49\end{array}$ & 0.50 & $\begin{array}{c}1 \cdot 0 \\
\text { or } \\
\text { above }\end{array}$ & \\
\hline Sputum & $\frac{2-3}{6}$ & $\begin{array}{l}22 \\
21^{1}\end{array}$ & $\begin{array}{l}4 \\
8\end{array}$ & $\begin{array}{l}3 \\
2\end{array}$ & $\begin{array}{l}2 \\
4\end{array}$ & 11 & $\begin{array}{l}2 \\
4\end{array}$ & $\begin{array}{l}0.52 \\
0.53\end{array}$ \\
\hline \multirow[t]{2}{*}{ Saliva } & 2 & $21^{2}$ & 8 & 4 & 5 & 2 & 2 & 0.32 \\
\hline & & & $<2.0$ & $\begin{array}{l}2 \cdot 0- \\
3 \cdot 9\end{array}$ & $\begin{array}{l}4 \cdot 0- \\
7.9\end{array}$ & $\begin{array}{r}8 \cdot 0 \\
15 \cdot 9\end{array}$ & $\begin{array}{c}16 \cdot 0 \\
\text { or } \\
\text { above }\end{array}$ & \\
\hline Serum & $\begin{array}{l}2 \\
6\end{array}$ & $\begin{array}{l}22 \\
21^{1}\end{array}$ & $\begin{array}{l}2 \\
8\end{array}$ & $\begin{array}{l}1 \\
6\end{array}$ & $\begin{array}{l}5 \\
5\end{array}$ & $\begin{array}{r}10 \\
2\end{array}$ & $\begin{array}{l}4 \\
0\end{array}$ & $\begin{array}{r}11 \cdot 0 \\
3 \cdot 5\end{array}$ \\
\hline
\end{tabular}

${ }^{1}$ One patient did not receive the 6.00 a.m. dose.

2 One patient could not produce saliva.

The mean two to three hours sputum level in patients with pneumonia was $0.57 \mu \mathrm{g} / \mathrm{ml}$ (range 0.03 to $2.00 \mu \mathrm{g} / \mathrm{ml}$ ). In patients with acute exacerbations of chronic bronchitis the mean level was $0.42 \mu \mathrm{g} / \mathrm{ml}$ (range 0.06 to $0.62 \mu \mathrm{g} / \mathrm{ml}$ ).

COMPARISON OF PURULENCE WITH AMOXYCILLIN LEVELS IN SPUTUM In Table II the sputum purulence is compared with the mean sputum

T A B L E I I

COMPARISON OF SPUTUM PURULENCE (ASSESSED BY THE NAKED EYE) WITH MEAN AMOXYCILLIN LEVELS

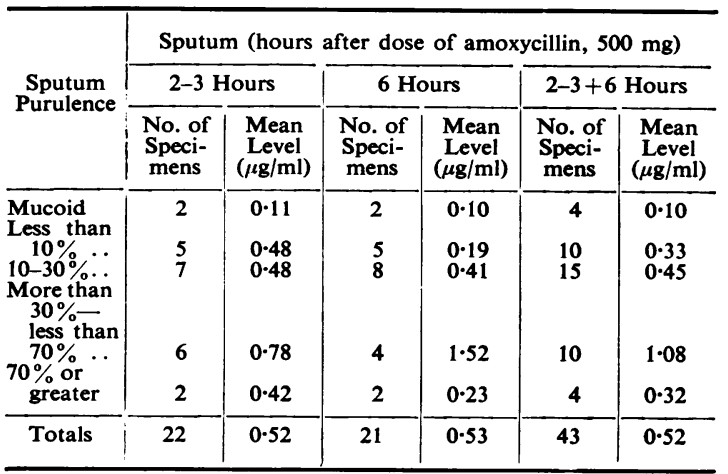


levels of amoxycillin at two to three hours and at six hours after administration. The numbers of specimens in each purulence group are small. However, when the results for the two to three hours and six hours specimens are combined, it is seen that the higher levels of amoxycillin are associated with the greater degrees of purulence apart from those specimens with $70 \%$ or more pus. In this latter group the levels were lower, though only four specimens from two patients were examined.

COMPARISON OF SPUTUM, SALIVA, AND SERUM LEVELS AFTER AMOXYCILLIN AND AMPICILLIN A comparison between the mean antibiotic levels in the sputum at two to three hours and in the saliva and serum at two hours after $500 \mathrm{mg}$ of amoxycillin and $500 \mathrm{mg}$ or $1,000 \mathrm{mg}$ of ampicillin is shown in Figure 1. The ampicillin levels were those found in similar patients in a previous investigation (Stewart et al., 1970). The mean levels of amoxycillin were significantly higher than those of ampicillin after the same dose. The levels in the sputum after $1,000 \mathrm{mg}$ ampicillin were similar to those after $500 \mathrm{mg}$ amoxycillin; the serum levels were higher after the ampicillin.

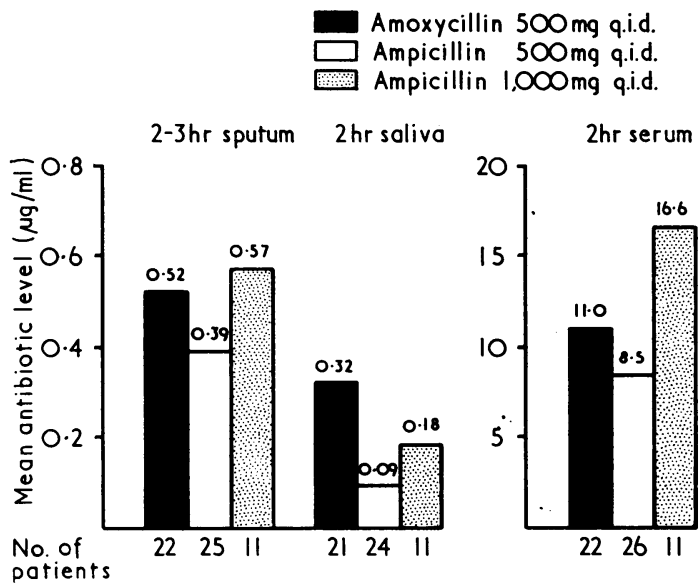

FIG. 1. Comparison of mean sputum, saliva, and serum levels after amoxycillin, $500 \mathrm{mg}$, ampicillin, $500 \mathrm{mg}$, and ampicillin, 1,000 mg, four times daily. The figures above the columns represent the mean antibiotic levels. (The ampicillin results are taken from a previous series (Stewart et al., 1970)).
CORRELATION OF CLINICAL RESPONSE WITH AMOXYCILLIN SPUTUM LEVELS Figure 2 shows the relationship between the clinical response and the amoxycillin level in the two to three hours sputum. The number of patients who responded by the seventh day was significantly greater in those with sputum levels of $0.25 \mu \mathrm{g} / \mathrm{ml}$ or above than in those with levels of less than $0.25 \mu \mathrm{g} / \mathrm{ml}$ $(0.02>P>0.01)$. The mean duration of fever in patients with pneumonia with levels of less than $0.25 \mu \mathrm{g} / \mathrm{ml}$ was 10.3 days compared with 4.1 days in those with levels of $0.25 \mu \mathrm{g} / \mathrm{ml}$ or above. In the bronchitics the mean times for the sputum to become mucoid were 12.3 and 4.0 days respectively.

Although there was a tendency for higher serum levels to be associated with a more rapid clinical response, the results were not statistically significant.

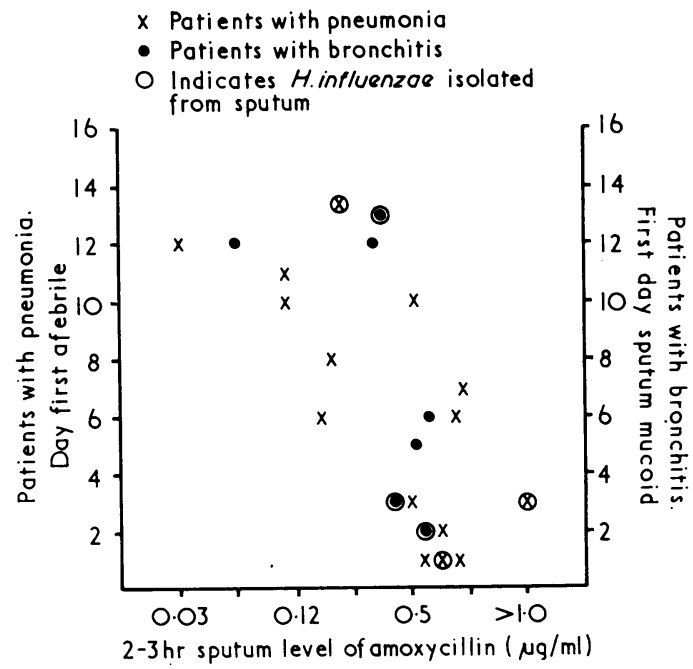

FIG. 2. Comparison of clinical response and two to three hours sputum levels in patients with pneumonia $(\Varangle)$ and bronchitis (O).

CLEARANCE OF PATHOGENS FROM SPUTUM The time taken to clear the pathogens from the sputum was related to the pathogen rather than to the amoxycillin level. $H$. influenzae was isolated on the second day of treatment from sputum from four out of five patients from whom this organism was cultured from the pretreatment specimen. Strept. pneumoniae was cultured from only one out of eight specimens obtained on the second day. All pathogens were cleared by the fifth day. 
COMPARISON OF SPUTUM LEVEL AND DURATION OF TREATMENT BEFORE ASSAY WAS CARRIED OUT There was no relationship between the duration of treatment prior to assay and the level of the drug in the sputum; all patients had received treatment for at least 36 hours.

BACTERIOLOGY OF SPUTUM AT TIME OF ASSAY No potential pathogens were isolated from the sputa at the time of assay. Coliform organisms were cultured from five specimens. The mean antibiotic level in the sputa from which coliforms were isolated was similar to that in the sputa from which no coliforms were cultured.

\section{DISCUSSION}

Croydon and Sutherland (1970) reported a mean serum level of $11.0 \mu \mathrm{g} / \mathrm{ml}$ two hours after a single dose of $500 \mathrm{mg}$ of amoxycillin given to volunteers after fasting. The level at six hours was $1.0 \mu \mathrm{g} / \mathrm{ml}$. These levels are similar to those found in the present series, in which the mean two-hour level was $11.0 \mu \mathrm{g} / \mathrm{ml}$ and the six-hour level $3.5 \mu \mathrm{g} / \mathrm{ml}$. The patients in the present study were not fasted before being given the test dose of the drug, but it was given preprandially. Croydon and Sutherland (1970) showed that the presence of food in the stomach at the time the dose was given did not affect the antibiotic level in the serum. The figures reported by May and Ingold (1972) are slightly lower, the mean twohour serum level being $7.7 \mu \mathrm{g} / \mathrm{ml}$.

The sputa examined in the present study were collected between the second and third hour and at the sixth hour after the dose. The mean levels were 0.52 and $0.53 \mu \mathrm{g} / \mathrm{ml}$ respectively. These levels are higher than those reported by May and Ingold (1972), who found levels of a 'trace' to $0.7 \mu \mathrm{g} / \mathrm{ml}$ in 24 -hour collections of sputum in patients receiving $500 \mathrm{mg}$ of amoxycillin sixhourly. The differences between these two series are not easy to explain. The dose of amoxycillin was the same. In May and Ingold's series the sputum assays were carried out on 24-hour collections of sputum while in the present study the sputa were collected over a period of one hour and assayed immediately. It has been shown that the presence of penicillinase-producing organisms in the sputum results in a lower sputum level of amoxycillin (May and Ingold, 1972). The collection of the sputum over a 24-hour period may allow the enzyme to break down the antibiotic in vitro, whereas the immediate assay of the specimens may reduce this activity to a minimum. May and Ingold's patients were predominantly cases of chronic bronchitis, whereas 15 of our 22 patients had pneumonia. In our series patients with pneumonia tended to have higher sputum levels, with a mean of $0.57 \mu \mathrm{g} / \mathrm{ml}$ compared to $0.42 \mu \mathrm{g} / \mathrm{ml}$ in specimens from patients with bronchitis. This may in part have accounted for the higher sputum levels in the present study. There may also be a technical difference in the assay method, since our mean serum levels, which agree well with those reported by Croydon and Sutherland (1970), were also higher than those reported by May and Ingold.

In the present series the clinical response was related to the level of antibiotic in the two to three hours sputum. There was a significantly higher number of patients showing response by the seventh day of treatment in the group whose two to three hours sputum level was $0.25 \mu \mathrm{g} / \mathrm{ml}$ or above than in those with lower levels. This suggests that the level of the drug in the sputum is of clinical importance. These findings are in accord with the results of May and Ingold (1972).

Croydon and Sutherland (1970) showed that serum concentrations of amoxycillin were nearly twice as high as those of ampicillin after similar doses of the drugs. In the present study, two to three hours sputum levels were significantly higher after $500 \mathrm{mg}$ amoxycillin than after $500 \mathrm{mg}$ ampicillin given to a similar series of patients in a previous study (Stewart et al., 1970) and were equivalent to the ampicillin levels obtained after doses of $1,000 \mathrm{mg}$ in that investigation.

The significant association between the more rapid clinical response and the higher sputum levels of amoxycillin together with the demonstration of significantly higher sputum levels of amoxycillin than of ampicillin after the same oral dose of $500 \mathrm{mg}$ given four times daily suggests that amoxycillin may be preferable to ampicillin at that dose for the treatment of bacterial respiratory infections. However, the two series quoted here were done at different times and it would be necessary to conduct a properly controlled trial of the two drugs in the treatment of such infections to establish the superiority of amoxycillin.

The authors are grateful to Professor J. W. Crofton, Dr. A. C. Douglas, and Dr. G. J. R. McHardy for allowing them to investigate their patients. Mr. W. Adams, of the Department of Social Medicine, carried out the statistical analysis. They also thank Mrs. A. S. Rankine for secretarial assistance. One of us (I.M.E.A.) was in receipt of a grant from the Chest and Heart Association. The amoxycillin was supplied by Beecham Research Laboratories Limited. 


\section{REFERENCES}

Croydon, E. A. P. and Sutherland, R. (1970). $\alpha$-Aminop-hydroxybenzylpenicillin (BRL 2333), a new semisynthetic penicillin; absorption and excretion in man. In Antimicrobial Agents and Chemotherapy, edited by G. L. Hobby, p. 427. American Society for Microbiology, Bethesda, Maryland.

Jones, G. R., Calder, M. A., Froud, W. J. B., Inglis, J. M., Marr, F. M., and Stewart, S. M. (1973). Amoxycillin: pilot study of its use in pneumonia and chronic bronchitis. British Journal of Clinical Practice, 27, 161.
May, J. R. and Ingold, A. (1972). Amoxycillin in the treatment of chronic non-tuberculous bronchial infections. British Journal of Diseases of the Chest, 66, 185.

Medical Research Council (1965). Definition and classification of chronic bronchitis for clinical and epidemiological purposes. Lancet, 1, 775.

Stewart, S. M., Fisher, M., Young, J. E., and Lutz, W. (1970). Ampicillin levels in sputum, serum, and saliva. Thorax, 25, 304. 